European Convention on Human Rights (see also the chapters which the author of this note contributed to Solly's Government and Law in the Isle of Man (1994) Chapter VI, 'European Convention for the Protection of Human Rights and Fundamental Freedoms', pages 189-211; Isle of Man Partnership Law (1996), Chapter III, 'Nature and Sources of Manx Law' pages 82 - 156, and pages 127-151 re: European Convention, which endeavours to summarise the position prior to the Act coming into full force).

\section{WAS THE STAFF OF GOVERNMENT DIVISION CORRECT IN REFERRING TO THE ADMINISTRATIVE DISCRETION POINT?}

Were the Staff of Government Division in the Jones case (as repeated in the Galloway case) correct to indicate that the Convention could be referred to 'to inform the exercise of an administrative discretion'? Or should they have deleted 'administrative' and inserted 'judicial', or should they have simply added the words 'or judicial' after the word 'administrative'?

On Frankland (1987-89 MLR 65) principles do we treat the English decisions, such as the House of Lord's Brind case (which appear to limit the reference to judicial discretion rather than administrative discretion) as highly persuasive, or do we follow the Jones case and the Galloway case (are they clear decisions to the contrary)? Should the Isle of Man courts follow the comments of the Judges of Appeal in the Jones case and the Galloway case and allow the Convention to be referred to 'inform the exercise of an administrative discretion'? Or should the Isle of Man courts follow the comments of Lord Bridge in the Brind case to the effect that to do so 'would be a judicial usurpation of the legislative function'?

The author's own view, for what it is worth, is that we should follow the stance taken by our Staff of Government Division (the Island's Court of Appeal) in the Jones case and the Galloway case rather than the stance taken by Lord Bridge in the Brind case. We should allow reference to the Convention to inform the exercise of judicial and administrative discretion.

If allowing reference to the Convention to inform the exercise of administrative discretion is considered unacceptable, the fall back position would be to accept that the human rights context is relevant to whether the relevant body exercising the administrative discretion acted reasonably and had regard to all relevant considerations. To limit reference to the Convention to inform only the exercise of judicial discretion would appear to be an unduly restrictive stance to take.

The administrative/judicial discretion debate will be academic as soon as the substantive provisions of the Act come into operation but in the meantime the Island's Court of Appeal - Staff of Government Division should clarify the position at the earliest available opportunity.

David Doyle

Chairman, Isle of Man Law Society's Human Rights Committec; Head of

Commercial Department, Dickinson Cruickshank \& Co, Advocates, Isle of Man (http://www.dc.co.im)

\title{
Globalisation and private international law: reviewing contemporary local law
}

\author{
by Olusoji Elias
}

$\mathrm{P}$ rimarily because territory necessarily features as an important basic denominator for cross-border interaction across national legal systems, there is a clear material affinity between private international law and the legal dimensions of globalisation. They both have a common root, firstly, in factors, characteristics and considerations concerning the scope of relevant laws, and also in the context and the terminology of localism and externalism. The complexity and the inclusive bearing of globalisation pose contemporary problems, and a recognisable broadening of the scope of private international law to meet the realities of a rapidly globalising world keeps with world-wide trends in which trans-national laws form an important primary focal point, whether or not as they are 
applied within forum states courts. The scope of local laws increasingly intersects with a public domain not distinctively associated with standard private international law.

The clearest expression of globalisation's provenance in cross-border communications and commerce - is to be found in the areas of commercial conflicts and cognate enforcement jurisdiction. Vischer had written that ' $[t]$ he international commercial contract, seen in its wider sense, is the motor of economic globalisation' ((1998/1999) 1 EJLR 203). However, there is also an entire, subtler and no less pervasive dimension from personal relations, crossborder torts and other non-commercial conflicts. Of the connecting concept of domicile, it is said that 'substantial connection with a place is the best indication of ...domiciliary intent' (Fentiman, (1991) 50 CLJ 445; Law Commission Rep. No. 168 (1987). In connection with lex mercatoria, although domestic law is 'concerned with and influenced by international matters, it develops within its own environment' (Rose (ed.), Lex Mercatoria Essays in International Commercial Law in Honour of Francis Reynolds (2000), p. xiv). Trans-border situations arising, be they contentious or otherwise (e.g. competition law, public regulation of companies), are not typically considered within the span of private international law, but it is in the nature of contemporary conflict of laws in action that they be considered and managed by private international lawyers. The influence of globalisation on the law is as tangible as it is profound.

The nexus between private international law and globalisation is about responsiveness to a relative interdependence of legal systems. Every rule of private international law potentially has a global geographic scope, revealing a variable legal answer to the pervasiveness of globalisation. These themes' affinity is qualitative because, for example, the conflicts rules of a given legal system reflect the degree to which that system accommodates situations arising from elsewhere. The affinity is quantitative in direct consequence of substantive modulation of traditional local law subject areas as they contend with and resolve legal issues arising from the rapid growth industry that is trans-national activity. Examples from contemporary private international law, especially in the avant garde subject areas, include: jurisdictional legal issues of trans-national environmental liability vis-à-vis their discrete conceptual analogues in the local law of nuisance (cf. re Union Carbide Corporation Gas Plant Disaster at Bhopal, India (1987) 809 F2d 195); substantive matters of intellectual property determined by close reference to territorially justified judicial jurisdictional rules ( $c$. Tyburn Productions Ltd $v$ Conan Doyle [1991] Ch 75); the survival of the role of nationality in respect of, e.g. EC trade mark law (Humphreys (2000) EIPR 405); restricting the expansion of cross-border bank mergers within the EC. The definition of private international law may require evaluation in serving modern requirements of a world-wide community of natural and legal persons, with a global public policy becoming more coherent and relevant.

This paper's designation reflects the bounds of its subject matter thus far outlined and illustrated. A chronological perspective would usefully bring relevant aspects of the historical development and the antecedents of either topic into focus, thus emphasising and explaining the modern requirements of either: reference to international legal conventions indicates the interactive deliberation of themes of legal unification and harmonisation and their contribution to producing local rules and principles over the decades. Latter day illustrations are the EC Brussels, Lugano and Rome Conventions, efficient halfway points between the strictly local and the immediate geographical region beyond. Theory and comparative methodology afford an important means of developing concepts and classifications of procedural law and the harmonisation of diverse national laws where necessary.

The paper draws attention to what may be called 'localisation': an inclusive functional response to globalisation and to the influential appeal and attraction of Cook's local law theory (Logical and Legal Bases of the Conflict of Laws (1942)) to the common law if not beyond. It also looks at the rigour with which public law is virtually emasculated from private international law even though there is an understated frame of practical application of general legal regulation, e.g. in personal relations, commercial law, company and corporate laws. The remainder of the paper looks mainly but not exclusively at trans-national civil litigation mainly from the perspectives of procedure and relief, the scope of applicable substantive law, international arbitration and modern lex mercatoria, and global public policy.

\section{TRANS-NATIONAL CIVIL PROCEDURE}

The high point of developments in international civil procedure has to be an evolving global jurisdiction and judgments convention. An important aspect of this is that rules of judicial jurisdiction generally sound at the verge of public law. Another is the scope for forms of domestic law in trans-national litigation. It is not unusual for several parties in different locations to be involved in the same cross-border litigation. Questions of the right forum, the correct relief, and the likelihood of success are typical, and jurisdictional rules are interpreted by courts and in the codes to provide answers. The sophistication and the detail of relevant rules suffice to show which national rules should apply in a given situation, such that divergences between systems (stemming, for example, from intrasystem legal pluralism) are to be seen in the terms of differences in national and public policy, rather than in terms of those systems' compatibility.

At the decisive level of local law, relevant national law will in some cases not have specifically provided for private international legal situations. Legal concepts (procedural, 
substantive and remedial) evolve from practical necessity, and they have to be justified by concrete legal principle. The House of Lords' ruling in Connelly v RTZ Corporation ([1997] 3 WLR 373), by which permission to sue in England and not in the proper forum (Namibia) - a point not dealt with in the local access to justice statute (the Courts and Legal Services Act 1990) - was found to depend on the parties' respective equities in the claim, shows that litigation in any civilised forum will probably always have variable advantages and disadvantages ( $c f$. the Hague Convention on International Access to Justice 1980). Similarly, the way in which cross-border civil disputes are characterised using international codes' special jurisdiction rules are to be seen to illustrate forum state caution in dealing with the pace and composition of international civil disputes.

The law of restitution conflicts is one such conceptual area not specifically provided for in most Common Law systems' international codes. One useful comparator is to be found in Article 127 of the Swiss Federal Act of International Private Law 1987, which gives unjust enrichment jurisdiction to its own state courts as long as the defendant is a local domiciliary, thereby substantially conforming with the Brussels Convention's defendantprotecting jurisdictional policy. Kleinwort Benson Limited v City of Glasgow City Council ([1999] 1 AC 153) is authority that a restitution claim is independent of contract and tort, and is therefore not quite dealt with under the otherwise versatile ( $c$. Jakob Handte et Cie GmbH v SA Traitements Mecano-Chiminiques des Surfaces (Case 26/91) ([1992] ECR 3967 (ECJ)) Article 5 of the Brussels Convention. On the restitutionary remedial front, the House of Lords has recently affirmed the viability of a new remedy of restitutionary damages: Attorney-General for England and Wales v Blake and Others ([2000] 3 WLR 625).

Other topics such as securities, trade competition and environmental liability can be seen to reflect a waning of the rationale for disapplying public interest issues in private international law. The trend produces an inclusive outlook without being necessarily expansionist or exotic in comparison with domestic law concepts. Much will turn upon the interdependence of autonomous jurisdictions whether and how a forum state court may exercise jurisdiction in consideration of all things, and what the response of any affected jurisdiction may be. Forum state restraint continues to be a prominent factor. In Union Eagle Limited $_{v}$ Golden Achievement Limited ([1997) 2 All ER 215), the Privy Council withheld discretionary specific performance of a sale of Hong Kong land on the equitable principle that it was not exceptional of the sellers to have neither waived their right to performance nor been estopped from having done so.

The rules on declining jurisdiction, on refusing judgment recognition and on negating substantive liability confirm that civil procedure is in general terms being irreducibly globalised, the necessary limitation being whether and how far unification or harmonisation is necessarily desirable, particularly where policy considerations are important. Jolowicz has pointed out (29 Amicus Curiae 4, at p. 5) the ramifications of the main practical difficulty - systems' structural compatibilities in the following way:

'The case for harmonisation of civil procedure and of the growth of regional organisations such as the European Union is simple enough. First there is the argument... that a citizen involved in an international dispute should not find his dispute dealt with by a different procedure according to the nationality of the court before which he comes. Secondly, there is the argument that any attempt to apply a more or less uniform substantive law in more than one jurisdiction is unlikely to produce uniform results if different jurisdictions deal with similar cases quite differently.'

\section{THE SCOPE OF APPLICABLE SUBSTANTIVE LAW}

Characterisation issues are generally less of a problem, especially in commercial conflicts. The United Kingdom's private international law of torts (Part III of the Private International Law (Miscellaneous Provisions) Act 1995) provides a good example. But first a look at the broader picture of cross-border torts. A 'Rome II Convention' (the European Group for Private International Law's 'Proposal for a European Convention on the Law Applicable to Non-Contractual Obligations' (1998) XLV NILR 465) is in progress to deal predominantly with trans-national torts. There is also important legal literature on the subject matter, such as Bar's recent work, The Common European Law of Torts, Volume I: The Core Areas of Tort Law, its Approximation in Europe, and its Accommodation in the Legal System (1998).

In keeping with modern legal life, fact-based subdivisions of classes of wrongdoing are varied. More to the present point, a preponderantly local attitude no longer characterises the legal system's disposition toward tort. The applicable law includes the flexible option of 'the law of the country in which the events constituting the tort or delict in question [occurred]' (section 11(1) of the 1995 Act) or, in exceptional circumstances, the law of the most significantly related legal system (sections $11(2)(\mathrm{c})$ and 12). Thus, torts committed abroad are localised without reference to domestic law even where applicable foreign tort law is not precisely reflected by local forms of action. The denominator is the convenience rather than the resistance of local law, thereby emphasising the importance of procedural unification as the precursor to substantive harmony.

\section{MODERN LEX MERCATORIA AND INTERNATIONAL ARBITRATION}

Mostly for reasons of its characteristically pronounced neutrality, flexibility and informality, there is probably no topic more consonant with the subject of this paper than the present one, subject of course to the point of 
definition by which the bygone self-validated market practice-led law merchant is to be differentiated from modern trans-national commercial law (see Lord Mustill in Bos and Brownlie (eds.), Liber Amicorum for Lord Wilberforce (1987), p. 149). Teubner had ventured that 'there are insights to be gained for lex mercatoria and other forms of global law without the state' (Global Law Without the State (1997), at p. 9). Lex mercatoria has substantial scope, as its sources include those derived from international legal and commercial practice, public international law (e.g. the United Nations Conference on International Trade Law (UNCITRAL) and the International Institute for the Unification of Private Law (UNIDROIT) forms and conditions), environmental liability, maritime law and practice, and pretty much whatever may be the subject matter ( $c$. Toope, Mixed Commercial Arbitration (1990), pp. 90-97; Wortmann (1998) 14 Arbitration International 97, at pp. 101-104).

Relevant to a modern account is the increased incidence of public legal issues such as in the contexts of agency (as with accessory liability: cf. Rt Hon Sir John Hobhouse in Rose (ed.), above, at p. 39), environmental liability (Gaskell, above, p. 71), and the accountability of public authorities contracting out (Craig, above, p. 321) which are really outside the scope of autonomous unregulated private transaction. The scope and attraction of lex mercatoria is all the more telling because parties/disputants enjoy a significant autonomy in choosing the law to govern them. The relationship between private international arbitration and lex mercatoria has been expressed in the terms of the latter being 'an important element' of the former (Mertens in Teubner (ed.), above, at p. 40).

Today, an arbitration clause is no longer seen to interfere with either courts' jurisdiction or public interest, given 'the increasing globalisation of business and the changing realities of a "new world market" which ignores traditional boundaries and distinctions' (Fortier (1997) 1 Int'lArbLRev 1) and that ' $[t]$ he evolution of arbitration as the preferred method for the resolution of international commercial disputes has resulted in the creation of a truly global Bar' (p. 2). Formalisation of national arbitral procedures increases ( $c$. the UNCITRAL Model Law-based Arbitration Act 1996) as does the harmonisation of an international code about which it is said that ' $[t]$ he emergence of a harmonised procedure may be one of the great benefits which international arbitration will bring to the legal world' (Sir Roy Goode in Rose (ed.), at p. 246). Change is attributable to international arbitration rather than to its domestic counterpart. Arbitral procedure has perhaps a larger geographical potential for integrating and dealing with trans-national legal activity.

Much the same principles are relevant to either adjudicators or arbitrators. But there can be difficulties in determining the governing law of an un-nationalised contract which does not express any choice of law, as well as in a corresponding want of resort to dispute resolution mechanisms other than litigation where the context is neither contract nor commercial. Likewise, the law of the place of arbitration and of arbitral awards determines much of the globalisation of arbitration practice, so that problems of cultural interaction are never really far from the agenda of international arbitrators. The burden is on national systems in the way in which they interpret their place in a global scheme.

\section{GLOBAL PUBLIC POLICY}

The importance of public policy as an overarching fact of general legal life and its place in private international law in particular (cf. Carter (1993) 42 ICLQ 1) are well accepted, even if opinion may differ as to how it is brought to bear on law in action in different jurisdictions (cf. Lagarde, Recherches sur l'ordre public en droit international prive (1959)). Recent specific examples of convergence include Article 16 of the Rome Contracts Convention, which excepts the diminution of a right established by reference to a foreign governing law where recoverable loss in the event of breach under that law contravenes public policy.

Apart from this type of debate concerned with whether public policy is construed in consistent terms across borders is the altogether more recent notion of a 'global public policy'. From all indications, it differs from international, if not necessarily local, public policy. It is furthered by the fact that there are important private international legal issues about which shared attitudes are discernible: an international morality ( $c$. Graveson (1980) Vol LI BYBIL 231, p. 234); preserving the global commons; deprecation of illegality and immorality; good sense; international comity, etc. The more tenable such themes are, the better formalisable and the more relevant to conventional law they could be.

Lord Simon spoke of an international public policy of 'common sense, good manners and a reasonable degree of tolerance' in Cheni v Cheni ([1965] P 85, p. 99) in the interests of a substantially fair resolution of the recognition of foreign marriages. Along with other legal subject areas, private international law must anticipate the defragmentation of miscellaneous levels of legal relation across borders, and with it the occurrence of civil society. Graveson had observed that ' $[\mathrm{t}]$ hroughout its history private international law has been far more independent of political considerations than has public international law'(as above, p. 251). International public policy has developed much further than global public policy in that foreign law is recognised within private international law.

Global public policy may have a more direct relevance to contemporary ius mercatoria in view of the fact that this is a law which, to some extent, Article 3(1) of the Rome Convention recognises as a selectable law (see also Articles 3, 9 and 10 of the Inter-American Convention on the Law Applicable to International Contracts 1994). It is of course 
related to questions of legal cultures and the inequalities of applicable laws in terms, among others, of their varied dispositions as to public policy, local conditions for the recognition and enforcement of judgments, treatment of foreign law as fact, and the orientation of legal considerations in the direction of forum law and local legislative preferences - what Graveson called issues of 'evolutionary depth' (loc. cit., pp. 242-252). As much as is categorical at the present time is the identification of the title of this section of the paper.

\section{OTHER GENERAL CONSIDERATIONS}

There are several other topics which deserve to be considered in this paper. They include the contemporary place of states and state organs on the one hand and, on the other, corporate trans-nationals, in private international law. States are eminently relevant to the discussion because of their changing role in a so-called global order, as parties to ordinary civil transactions and disputes as subjects of private international law; the nature of their participation in and subscription to international conventions; the importance of state policy in these respects; and so on. The erosion of the province of statehood in the global age is in large part directly founded on the evolution of the jurisdictional rules of civil litigation, by which the proper limits of state sovereignty and immunity are described. Yet, it is a little impractical to expansively consider, for example, the polemical nature of international attempts to streamline systems of world trade by reference to familiar terms and methods of private international law, even though the broad terms of analysis (e.g. issues of nomenclature - governing law, agreed forum, etc.- and dispute resolution mechanisms, etc.) may be identical in either scenario. Jurisdictional efficiency continues correctly to dictate recourse to public international law and its designated institutions and mechanisms without suggesting that there is little of interest to the private international lawyer.

There are also several worthy perspectives from professional law, given that several aspects of legal globalisation and professional legal practice are practitioner-led: the increased profile of human rights issues; professional regulation; multidisciplinary transnational legal practice (see generally Harper (ed.), Global Law in Practice (1997)).

In qualitative terms, modern conflict of laws is driven by its ability to effectively respond to today's trans-national circumstances (cf. McLachlan (1998) 47 ICLQ 3). Relevant rules of private international law will often have to reach ahead in some of the fact situations arising before the courts. It is unremiss to underscore the localist subtext of this paper for the simple reason that the technical adequacy of conflicts rules applied by a forum state court cannot usefully be considered away from their origin as legal rules.

'Local' today encompasses domestic law, regional law, derivations from foreign law and, indeed, trans-national and international laws. It is hardly revivification to look to local law theory in the global present for it is precisely in the context of legal globalisation that the local and its verbal derivatives belong and ought to flourish. This requires that external elements must be relevant and applicable to the situation, rather than that they must be compatible with a domestic law comparator applicable in a domestic case. A forum state court's ability to apply a legal rule involves rational discernment, and the law of the forum never meant domestic law exclusively. The jurisdictionconferring rules of the Brussels Convention and the scope of the doctrine of forum non conveniens indicate that there is little in the nature of recondite relapse to classical conflict of laws wherein the forum rigorously avoided being an amorphous vector whose adjudicatory processes could be permeated by external factors. Discretion-based jurisprudence and the strictures of codified law together constitute formal adjudication ( $c f$. Continental Bank v Aeakos Compania Naviera [1994] 1 WLR 588) in the global age in which making legal localism more contemporary is a priority. An inclusive legal localism in the global present, it is submitted, is the best explanation for private international law today.

\section{CONCLUSION}

Private international law involves the formation and application of international legal codes for a diversified world. Its complex overlaps with public international law may be seen to justify enquiry into whether its progress will foreseeably exclude considerations deriving from public international law, for example, of international trade. Although there is a specified variety of competent courts to deal with the diversity of trans-national legal issues, those courts do not overtly interpret political culture as part of their principled jurisprudence nor does the public interest quite suffer in a private law situation. It is unlikely that Vischer's 'displacement of the significance of private international law' (above, at p. 216) can ensue, even if local as well as foreign public law is necessarily still excluded from textbook conflict of laws as well as from the way in which a potential multiple-issue trans-national cause of action is normally conceptualised and disposed of.

The global present is about a responsive broadening of the scope of local law as general regulation, within the principled parameters of law as convention. There is every reason to look to the continued progress of general transnational law, and private international law in particular, to respond to contemporary legal requirements.

\footnotetext{
Olusoji Elias

Member of the International Bar Association; author of Judicial Remedies in the Conflict of Laws (Hart Publishing Ltd, 2001). This paper is the revised text of a lecture delivered at the Society for Advanced Legal Studies in November 2000
} 